\title{
PENGARUH PEMAHAMAN WRITING MATHEMATICS MAHASISWA DALAM MENGKOMUNIKASIKAN SUATU BUKTI PERNYATAAN DALAM MATEMATIKA
}

\author{
Intan Nisfulaila \\ Matematika, UIN Maulana Malik Ibrahim Malang \\ i.nisfulaila@uin-malang.ac.id
}

\begin{abstract}
Abstrak
Kemampuan menulis dan mengkomunikasikan teks Matematika diperlukan untuk mendapatkan pemahaman yang utuh terhadap suatu materi dalam Matematika. Kemampuan menulis teks Matematika yang baik dan benar dapat dijadikan sebagai suatu indikasi bahwa penulis tidak hanya sekedar menghafal melainkan juga memahami apa yang sedang ditulis serta dapat dijadikan sebagai suatu tolak ukur bahwa penulis memahami alur cerita yang disampaikan kepada pembaca. Namun demikian masih banyak ditemukan adanya kalimat tidak bermakna dan penggunaan simbol-simbol Matematika yang tidak sebagaimana mestinya. Hal ini dapat menyebabkan munculnya miskonsepsi dan anggapan bahwa yang disampaikan sudah benar sesuai kaidah. Pada penelitian ini analisis data dilakukan secara kualitatif untuk meninjau seberapa besar perubahan writing mathematics skill setelah sekelompok mahasiswa mendapatkan bimbingan teknis. Hasil analisis data dan evaluasi menunjukkan bahwa kemampuan memahami kaidah writing mathematics berpengaruh dalam mengkomunikasikan atau meng-create suatu bukti pernyataan matematis, meskipun secara kualitatif perubahannya tidak terlalu signifikan.
\end{abstract}

Kata kunci: Menulis, Teks Matematika, Mengkomunikasikan, Bukti

\begin{abstract}
The ability to write and communicate Mathematical texts is needed to get a complete of understanding of a material in Mathematics. The ability to write good and correct Mathematics texts can be used as an indication that the writer is not only memorizing but also understanding what is being written and can be used as a measure that the writer understands the storyline that is conveyed to the reader. However, there are still many meaningless sentences and inappropriate use of Mathematical symbols. This can lead to misconceptions and the assumption that what is conveyed is correct according to the rules. In this study, data analysis was carried out qualitatively to review how much change in writing mathematics skills has occurred after a group of students received technical guidance. The results of data analysis and evaluation show that the ability to understand the rules of writing mathematics has an effects in communicating or creating proof of mathematical statements, although qualitatively the changes are not too significant.
\end{abstract}

Keywords: Writing, Mathematics Text, Communicating, Proof 


\section{PENDAHULUAN}

Houston di dalam bukunya menuliskan alasan dari pertanyaan "why writing well is good for you". Menulis dengan baik dan jelas sangat penting ketika kita berharap agar suatu tulisan dapat dimengerti (Houston, 2009). Selain itu, menulis dengan baik mempunyai bonus yaitu mengklarifikasi materi yang sudah dipelajari dengan komunikasi yang baik sehingga menambah pemahaman pembaca. Secara umum, jika kita ingin menjelaskan suatu hal ke orang lain, ada dua hal yang harus kita ingat diantaranya bermurah hati kepada pembaca (tidak mempersulit pembaca) dan tanggung jawab secara komunikasi (jika orang yang sama tingkatannya dengan kita tidak dapat memahami tulisan kita, artinya permasalahan penulisan ada pada kita).

Berdasarkan nilai dari penugasan writing skill kepada 85 mahasiswa semester 1 dan 3 Jurusan Matematika Universitas Islam Negeri Maulana Malik Ibrahim Malang, masih banyak yang mengkomunikasikan penyelesaian masalah Matematika seperti memberikan kertas hasil perhitungan kepada pembaca dikarenakan tulisan yang dibuat tidak bermakna, atau "tidak berbunyi". Terdapat juga penggunaan simbol yang memberikan makna kurang jelas terhadap kalimat yang dibentuk. Padahal kita harus dapat memahami beberapa simbol yang ada pada bahasa resmi kemudian menghubungkannya dengan cara sedemikian rupa dengan suatu struktur matematika (Leary dan Kristiansen, 2015).

Hal ini masih wajar bagi mahasiswa baru dikarenakan mereka baru memasuki dunia perkuliahan. Namun bagi mahasiswa yang sudah berada di semester 3, tentu saja hal ini menjadi suatu keprihatinan dikarenakan seharusnya mereka sudah mulai mempraktekkan bagaimana menulis (penyelesaian soal Matematika) dengan baik. Pemahaman yang baik pada sistem logika diperlukan sebagai suatu solusi. Sistem logika yang sudah ada dibangun dari hasil penelitian pada suatu bahasa (bahasa matematika) (Mesnil, 2017). Selain itu juga bahwa logika matematika merupakan salah satu unsur pokok dalam landasan matematika disamping himpunan, relasi, dan fungsi (Susilo, 2012). Hal inilah yang menjadi salah satu alasan keurgency-an pengangkatan topik dalam kegiatan penelitian ini.

Harapan daripada dianalisisnya perkembangan kemampuan mahasiswa dalam menuliskan pemahamannya adalah karena pentingnya belajar logika yang diantaranya adalah membantu seseorang untuk berpikir lurus, tepat, dan teratur (Sudrajat, 2017). Dengan berpikir lurus, tepat, dan teratur seseorang akan memperoleh kebenaran dan terhindar dari kesesatan.

Topik dalam penelitian ini difokuskan pada logika dan penalaran yang merupakan dua hal mendasar dalam Matematika. Studi mengenai logika berawal dari pernyataan. Pernyataan adalah suatu kalimat atau ekspresi 
matematis yang bernilai salah saja atau bernilai benar saja (Hammack, 2013). Ada juga yang menyebutkan bahwa pernyataan adalah kalimat deklaratif yang dimungkinkan untuk memberikan suatu nilai kebenaran, nilai benar saja atau nilai salah saja (Dalen, 2013). Selain itu, secara tata bahasa, sebuah kalimat atau pernyataan harus memiliki pokok kalimat atau pokok persoalan dan kata kerja yang menggambarkan apa yang dilakukan atau terjadi pada pokok persoalan tadi (Tirta, 2011).

Pernyataan memerlukan suatu prosedur untuk membuktikan kebenarannya atau untuk menyangkalnya dengan memberikan contoh kontra. Prosedur yang dimaksudkan adalah serangkaian tulisan yang dapat dipertanggungjawabkan secara matematis baik dalam hal isi maupun teknis. Namun dalam prosesnya kita perlu berhati-hati dalam membedakan mana yang diketahui (diasumsikan), mana yang dibuat, dan mana yang dibuat deduksinya berdasarkan informasi yang sudah diketahui dan dibuat (Gilbert dan Gilbert, 2009).

Berdasarkan pendapat Gilbert tersebut, penyampaian bukti yang baik bergantung kepada pemahaman yang dimiliki mahasiswa dalam menuliskan informasi apa saja yang sudah diperoleh dan bagaimana meramunya. Dalam penelitian ini akan dikaji secara kualitatif bagaimana pengaruh kemampuan menulis teks matematika (writing mathematics) mahasiswa dalam menuliskan bukti suatu pernyataan dalam matematika. Hasil kajian penelitian ini diharapkan mampu memberikan gambaran dan pelajaran kepada mahasiswa mengenai pengetahuan dan wawasan yang diperlukan agar dapat menuliskan, khususnya mengkomunikasikan hasil belajar mandirinya dalam bentuk tulisan atau teks matematika dengan baik dan benar. Secara terperinci, logika digunakan untuk membantu setiap orang yang mempelajari logika untuk berpikir secara rasional, kritis, lurus, tetap, tertib, metodis dan koheren (Sobur, 2015). Logika sendiri tidak semata-mata lahir sebagai sebuah cara berfikir dalam memandang hidup yang tersusun rapi, namun sejatinya ia mengalami proses yang dimulai dari logika sebagai metode berfikir (Musthofa, 2016).

Manfaat logika selain yang disebutkan sebelumnya oleh Sobur adalah banyak teorema (pernyataan yang bersifat penting dan dapat dibuktikan) di dalam ilmu komputer atau informatika yang membutuhkan pemahaman logika (Fauzi, 2015). Selain itu,

"Banyak pemikir menyatakan bahwa untuk menjadi lawyer, hakim, jaksa, atau praktisi hukum yang handal, pemahaman terhadap logika, penalaran hukum, dan argumentasi hukum merupakan syarat mutlak yang tak bisa ditawar-tawar. Karena logika, penalaran hukum, dan argumentasi hukum membekali para mahasiswa hukum, pekerja hukum, dan praktisi hukum dengan kemampuan berpikir kritis dan argumentatif dalam 
memahami prinsip, asumsi, aturan, proposisi, dan praktik hukum." (Weruin, 2017)

Dua hal tersebut merupakan motivasi bagi mahasiswa yang ingin memperdalam atau studi lanjut dalam bidang ilmu komputer atau informatika serta ilmu hukum.

\section{METODE PENELITIAN}

Hasil dalam penelitian ini diperoleh melalui serangkaian metode penelitian kualitatif yang dilakukan di lingkunga UIN Maulana Malik Ibrahim Malang pada semester genap tahun ajaran 2019/2020. Langkah pertama adalah melakukan survei terhadap 35 mahasiswa Jurusan Tadris (Pendidikan) Matematika dan 69 mahasiswa Jurusan Matematika melalui pengisian kuesioner. Responden terdiri dari mahasiswa semester 1 sebanyak 42 mahasiswa, mahasiswa semester 3 sebanyak 30 mahasiswa, dan mahasiswa semester 5 sebanyak 32 mahasiswa dengan catatan terdapat 4 mahasiswa yang mengisi sebanyak dua kali sehingga tercatat sebagai 104 tanggapan, namun pada kenyatannya hanya terdapat 100 tanggapan kuesioner.

Langkah kedua adalah mengolah data hasil survei yang akan dijadikan sebagai acuan dalam menentukan langkah apa yang akan digunakan untuk mengetahui seberapa besar pengaruh wawasan dan pemahaman mahasiswa mengenai writing mathematics terhadap "gaya" mahasiswa dalam mengkomunikasikan suatu bukti pernyataan dalam matematika. Data yang diolah berupa data pendapat seberapa penting pemahaman menulis/mengkomunikasikan teks Matematika sebagai indikator dalam memahami suatu materi dalam Matematika, data berbagai kesulitan mahasiswa saat menulis/mengkomunikasikan teks hasil penyelesaian suatu soal matematika, data konten yang dipilih jika di kemudian hari akan disusun suatu modul writing mathematics, dan data kelemahan yang dirasakan sebagai penghambat dalam belajar matematika, terutama dalam menulis/mengkomunikasikan penyelesaian soal matematika.

Selanjutnya langkah ketiga adalah melakukan kegiatan bimbingan teknis yang diikuti oleh hampir 50\% dari jumlah responden survei. Dalam kegiatan tersebut dipaparkan materi mengenai writing mathematics skill, dilakukan kegiatan pre-test dan post-test yang hasilnya digunakan untuk mengukur pemahaman mahasiswa mengenai writing mathematics. Langkah terakhir yaitu melakukan analisis data hasil pre-test dan post-test yang kemudian disampaikan kepada responden yang dapat dijadikan sebagai referensi pembelajaran. 


\section{HASIL DAN PEMBAHASAN}

Bagian ini akan ditampilkan data pendapat seberapa penting pemahaman menulis/mengkomunikasikan teks Matematika sebagai indikator dalam memahami suatu materi dalam Matematika, data berbagai kesulitan mahasiswa saat menulis/mengkomunikasikan teks hasil penyelesaian suatu soal matematika, data konten yang dipilih jika di kemudian hari akan disusun suatu modul writing mathematics, dan data kelemahan yang dirasakan sebagai penghambat dalam belajar matematika, terutama dalam menulis/mengkomunikasikan penyelesaian soal matematika. Berikut ini yang pertama adalah data ke-urgency-an Writing Mathematics.

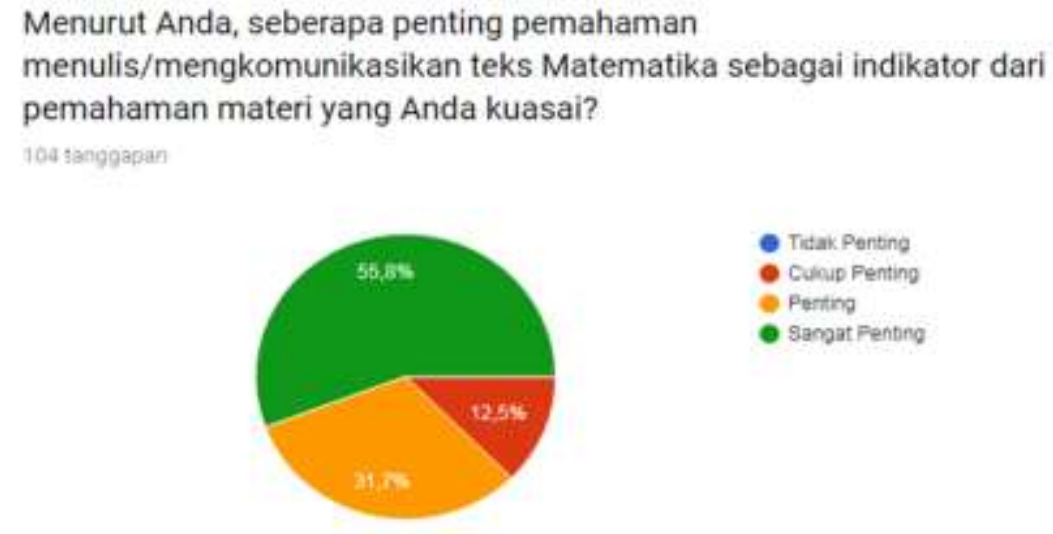

\section{Diagram 1. Diagram Lingkaran Ke-urgency-an Writing Mathematics}

Data berbagai kesulitan mahasiswa saat menulis/mengkomunikasikan teks hasil penyelesaian suatu soal matematika.

Tabel 1. Data Jenis Kesulitan Mahasiswa

\begin{tabular}{|c|c|c|c|c|c|}
\hline No & Jenis Kesulitan & $\%$ & No & Jenis Kesulitan & $\%$ \\
\hline 1 & Sulit memahami soal & 28,8 & 9 & $\begin{array}{l}\text { Bingung menggunakan } \\
\text { simbol yang seharusnya } \\
\text { dipakai }\end{array}$ & 16,3 \\
\hline 2 & $\begin{array}{l}\text { Sulit memahami materi dasar } \\
\text { yang dibutuhkan }\end{array}$ & 21,2 & 10 & $\begin{array}{l}\text { Merasa tertekan saat } \\
\text { dikejar waktu (saat ujian) }\end{array}$ & 21,2 \\
\hline 3 & $\begin{array}{l}\text { Tidak memahami materi dasar } \\
\text { namun belum berusaha untuk } \\
\text { memahami }\end{array}$ & 17,3 & 11 & $\begin{array}{lrr}\text { Sering } & \text { merasa } & \text { tidak } \\
\text { percaya diri } & \text { untuk } \\
\text { berkonsultasi } & \text { tentang } \\
\text { materi yang belum } & \text { paham }\end{array}$ & 1,9 \\
\hline 4 & $\begin{array}{l}\text { Tidak memahami materi dasar } \\
\text { yang dibutuhkan meskipun } \\
\text { sudah berusaha memahami }\end{array}$ & 28,8 & 12 & Susah mencari clue & 1 \\
\hline
\end{tabular}

Prismatika: Jurnal Pendidikan dan Riset Matematika Vol. 3 No. 2 (2021)

p-ISSN: 2654-6140, e-ISSN: 2656-4181

http://ejurnal.budiutomomalang.ac.id/index.php/prismatika 


\begin{tabular}{|c|c|c|c|c|c|}
\hline 5 & $\begin{array}{l}\text { Bingung memilih kata-kata } \\
\text { yang sebaiknya dipakai untuk } \\
\text { menjelaskan }\end{array}$ & 51,9 & 13 & Kurang kreatif & 1 \\
\hline 6 & $\begin{array}{l}\text { Kurang berlatih } \\
\text { menulis/mengkomunikasi-kan } \\
\text { hasil penyelesaian soal } \\
\text { Matematika }\end{array}$ & 58,7 & 14 & Malas & 1 \\
\hline 7 & $\begin{array}{l}\text { Enggan membaca referensi } \\
\text { berbahasa Inggris }\end{array}$ & 32,7 & 15 & $\begin{array}{l}\text { Penjelasan dosen yang } \\
\text { kadang terlalu cepat atau } \\
\text { bertele-tele }\end{array}$ & 1 \\
\hline 8 & $\begin{array}{l}\text { Kurang mengenal simbol- } \\
\text { simbol yang sering digunakan }\end{array}$ & 18,3 & & & \\
\hline
\end{tabular}

Selanjutnya adalah data konten yang dipilih jika di kemudian hari akan disusun suatu modul writing mathematics.

Tabel 2. Data Konten Modul yang Dipilih

\begin{tabular}{clc}
\hline No & \multicolumn{1}{c}{ Jenis Konten } & \% \\
\hline 1 & $\begin{array}{l}\text { Tips umum dalam menulis/mengkomunikasikan penyelesaian suatu } \\
\text { soal Matematika }\end{array}$ & 55,8 \\
\hline 2 & Contoh yang mendukung tiap tips & 36,5 \\
\hline 3 & $\begin{array}{l}\text { Beberapa contoh dalam mengkomunikasi kan hasil penyelesaian soal } \\
\text { Matematika }\end{array}$ & 45,2 \\
\hline 4 & Metode pembuktian dalam Matematika & 49 \\
\hline 5 & $\begin{array}{l}\text { Contoh pembuktian untuk setiap metode beserta highlight bagian- } \\
\text { bagian yang sering tidak diperhatikan mahasiswa }\end{array}$ & 61,5 \\
\hline
\end{tabular}

Terakhir adalah data kelemahan yang dirasakan sebagai penghambat dalam belajar matematika, terutama dalam menulis/mengkomunikasikan penyelesaian soal matematika.

Tabel 3. Data Opini Tiap Responden Tentang Kelemahan yang Dirasakan

\section{Kelemahan}

1. Bingung bagaimana cara mengawalinya, kesulitan memilih kata-kata yang komunikatif dan memahami konsep materi. Solusinya banyak berlatih mengerjakan soal dan memperbanyak belajar.

2. Malas.

3. Sulit dalam pembuktian konsep dasar solusinya terus belajar memahami.

4. Sulit berkata-kata.

5. Belum mengetahui jenis soal, kurang hafal mengenai simbol-simbol dalam matematika.

6. Sulit mengkomunikasikan jawaban soal kepada teman, lebih berlatih untuk berkomunikasi dan sering-sering memahami penjelasan dari guru.

7. Memahami bahasa matematika.

8. Saya merasa sulit mengkomunikasikan krn tidak faham secara detail materi tersebut.

9. Daya berpikir yg kurang cepat dalamm menyelesaikan soal.

Prismatika: Jurnal Pendidikan dan Riset Matematika Vol. 3 No. 2 (2021)

p-ISSN: 2654-6140, e-ISSN: 2656-4181

http://ejurnal.budiutomomalang.ac.id/index.php/prismatika 
10. Sulit memahami konsep.

11. Sulit nya memilih kata-kata untuk mengkomunikasikan soal matematika.

12. Kurang memahami materi dasar. Sehingga ketika diteruskan, menjadi sulit dipahami. Solusi : mempelajari dari awal.

13. Tidak tahu suatu tanda baca itu harus dipakai pada saat apa.

14. Memahami konteks soal.

15. Karena saya awalnya tidak ingin disini.

16. Lemah untuk memahami materi jika tidak diterangkan.

17. Tidak paham apa yang dimaksud.

18. Terkadang jarang paham materi.

19. Kurangnya berlatih menulis sehingga sulit untuk mengkomunikasikannya.

20. Kelemahan saya ada pada permisalan yang kita dituntut lebih menggunakan logika.

21. Kurang mengetahui clue awal dalam mengerjakan soal dan pembuktian. Kurang mampu membahasakan dalam bahasa matematika.

22. Lemahnya dalam penalaran logika dan pembuktian, solusinya mungkin bisa dibentuk tentor sebaya sebagai pendukung lain untuk melatih dan mengajari kita yg masih kurang paham dalam materi.

23. Malas mencoba.

24. Kelemahan : 1) Kurang berlatih dan belajar. 2) Pemilihan kata-kata agar penyelesaian Matematika dapat lebih mudah dipahami. 3) Tidak memahami konsep dasar materi tersebut. 4) Kurang percaya diri apalagi ketika dihadapkan dengan situasi Ujian. Solusi : Banyak membaca dan mencoba.

25. Kelemahan saya terletak pada pemahaman konsep.

26. Kurang memahami cara mengungkapkan suatu penyelesaian matematika.

27. Dasar matematika yang belum paham.

28. Untuk memulai dari mana masih bingung dan dasar konsep pada teori yang gampang lupa dan ada yang masih belum paham.

29. Kurang tepat dalam memilih kata.

30. Kurangnya pemahaman dalam menjelaskan soal Matematika.

31. Kurang memahami materi meskipun sudah berusaha maksimal.

32. Kurangnya pemahaman materi dasar, dan kurang terbiasa untuk mengkomunikasikan penyelesaian soal matematika dengan menggunakan kalimat.

33. Kelemahan saya adalah ketika saya telah mencoba mengerjakan matematika tapi saya tidak menemukan penyelesaiannnya sehingga saya malas untuk melanjutkan,solusinya saya akan menghilangkan rasa malas saya.

34. Kelemahannya dalam memahami soal bentuk cerita. Solusinya dengan banyak latihan dan bimbingan dari orang lain.

35. Memahami maksud materi terkadang faham tapi bingung ketika menghadapi soal.

36. Saya belum mengenal semua simbol yang ada dalam matematika, saya juga kurang mengetahui bahasa yang baik yang biasa digunakan dalam ilmu matematika. Sehingga ketika mengkomunikasikan solusi pada matematika, saya merasa bingung tentang apa yang harus saya jelaskan, tetapi saya sudah paham akan apa yang saya tulis.

37. Kurang memahami pembuktian matematika. Solusinya adalah banyak latihan.

38. Kurang pengetahuan tentang simbol-simbol yang harus digunakan.

39. Sulit memahami beberapa soal dan solusinya diskusi dengan teman dan menanyakan kepada dosen. 
40. Terjemah buku, dan pemahaman materi, serta nalar soal.

41. Memahami tujuan dari soal dan rumus yabg digunakan untuk menyelesaikannya.

42. Memahami soal.

43. pemahaman konsep yang mendalam serta latihan yang berkelanjutan merupakan tonggak serta pondasi dalam memperdalam matematika.

44. Menentukan maksud soal dan cara mengkomunikasikan hasil penyelidikannya.

45. Bingung harus memulai/menulis kata-katanya secara tepat, dan terkadang tidak paham dengan maksud dalam soal tersebut.

46. Buku yang berbahasa Inggris.

47. Bingung memilih kata kata yang digunakan.

48. Sulit mengutarakan kata kata yang akan dipakai untuk menjelaskan.

49. Kurangnya memahami materi dasar dan sulit dalam memilih kata yang akan dituangkan dalam menulis.

50. Saya merasa masih bingung dalam hal memilih atau menggunakan kata-kata yang tepat dalam mengkomunikasikan suatu soal matematika, selain itu saya masih bingung dalam penggunaan tanda-tanda di matematika.

51. Karena tidak mengetahui materi dasar, maka saya tidak bisa memahami materi selanjutnya. Jika materinya saja saya belum matang, maka untuk menjelaskan ke orang lain jadi tidak bisa.

52. Kurang pandai merangkai kata kata. Solusi nya sering berlatih dengan melihat contoh.

53. Sulit memahami teori atau materi dasar.

54. Enggan membaca referensi dan seringkali lebih suka yang instan-instan.

55. Kurangnya rasa ingin tahu tentang asal suatu materi atau teorema.

56. Kurangnya motivasi dan harus seringkali meng-upgrade motivasi yang sering down.

57. Sulit membangun mood.

58. Terkadang sudah susah payah memahami teori dasar yang akhirnya paham tetapi saat ujian seperti berhadapan dengan materi asing.

59. Pada soal pembuktian. Kelemahan saya jika mengerjakan soal bentuk cerita, agak sulit untuk memahami maksud dari soal cerita tersebut.

60. Malas mempelajari cara menulis /mengkomunikasikan penyelesaian soal dengan baik.

61. Malas yang berlebih, solusinya belajar dengan giat.

62. Dalam berhitung saya cenderung lambat. Untuk itu saya akan berlatih mengerjakan soal dengan lebih cepat lagi.

63. Kurang mengenal simbol simbol, maka harus banyak membaca, berlatih dan mengingat makna simbol simbol.

64. Sulit mengingat rumus matematika.

65. Penggunaan simbol yang sangat kurang dimengerti.

66. Bingung ketika tidak memahami soal tanya ke siapa.

67. Malas latihan soal.

68. Di saat pembuktian, harus berfikir sekreatif mungkin untuk mencapai pembuktian.

69. Belum mengetahui simbol simbol yang ada.

70. Bingung memulai dari mana dan bingung menggunakan kata-kata ataupun simbol yang harusnya digunakan.

71. Kurang memahami soal atau penjelasan yang menggunakan bahasa Inggris.

Prismatika: Jurnal Pendidikan dan Riset Matematika Vol. 3 No. 2 (2021)

p-ISSN: 2654-6140, e-ISSN: 2656-4181

http://ejurnal.budiutomomalang.ac.id/index.php/prismatika 
72. Tidak memahami materi dasar materi, aplikasi soal yang berbeda beda hingga sulit untuk mengerjakannya. Sedangkan yang dipahami hanya 1 aplikasi saja

73. Lamban dalam pemahaman maksud soal, solusinya mungkij dengan sering berlatih mengerjakan soal matematika.

74. Saya masih lambat dalam memahami dalam penyelesaian matematika.

75. Sulitnya memilih kata-kata dengan benar. Solusi: terus berusaha.

76. Kurang berlatih.

77. Kurang memahami konsep dan jarang berlatih menulis.

78. Bingung memahami bahasa yang digunakan dalam buku, terkadang bingung memulai langkah awal.

79. Memahami soal dan rumus yang harus digunakan.

80. Cara menulisnya Solusinya dengan banyak berlatih dan banyak membaca.

81. Tidak mudah dalam memahami konsep dan memahami penyelesaian soal yang dibutuhkan.

82. Bingung dalam mengkomunikasikan maksud yang saya mengerti dalam penyelesaikan.

83. Bingung dalam awal penulisan, dan bingung menggunakan teorema yang mana. Karena terkadang belum memahami dengan baik, perlu waktu yang lama agar dapat memahami soal.

84. Kurang mengenal simbol-simbol dalam matematika.

85. Susah memahami maksud soal dan kadang salah mengaplikasikannya. Solusinya mengerjakan atau berlatih lebih banyak soal soal, jika masih belum mengerti bertanya kepada teman yang paham untuk minta penjelasan atau langsung ditanyakan ke dosen pengampu mata kuliah.

86. Sulit memahami kata maupun kalimat matematika dan materi dasar untuk belajar lanjutan.

87. Kesulitan yang saya alami yaitu memahami soal dan menulis dengan kata-kata yang tepat.

88. Belum bisa memahami dan sulit untuk menggunakan simbol.

89. Bingung memilih kata kata dalam mengkomunikasikan penyelesaian soal matematika dan memahami konsep dasar dalam soal.

90. Masih dalam berlogika. Saya rasa, pikiran saya masih rumit, sehingga untuk menyelesaikan suatu soal, memerlukan waktu yang lama.

91. Kurangnya membaca dan latian dalam belajar matematika.

92. Kurang memahami simbol-simbol yang digunakan.

93. Sulit memahami soal solusinya yaitu selalu berusaha berlatih memahami, menulis dalam menyelesaikan soal.

94. Waktu diterangkan paham dan setelah kadang membingungkan setelah melihat soal lain.

95. Kurang latihan soal-soal, solusinya hanya dengan menambah latihan.

96. Susah memahami dasarnya.

97. Saya terkadang merasa kesulitan untuk memahami materi, lebih utamanya

98. Kurang dalam ketelitian solusi tidak boleh tergesa-gesa, hanya memahami setengah dari materi, tidak paham konsep \& tujuan materi.

99. Kurang berlatih dan enggan membaca referensi berbahasa Inggris. Solusi saya, menggunakan video pembelajaran dan google translate.

100. Terkadang sulit memahami soal. 
Karena soal pre-test dan post-test sama, berikut hanya ditampilkan untuk lembar post-test.

\section{NAMA \\ JURUSAN \\ SEMESTER \\ LEMBAR SOAL POST TEST \\ BIMBINGAN TEKNIK WRITING MATHEMATICS}

1. Seorang pedagang membeli 3 kodi pakaian dengan harga $R p \quad 600.000$,perkodi. Pakaian tersebut ia jual kembali dengan harga Rp 400.000,-per lusin. Dalam waktu dua hari pakaian tersebut sudah habis. Berapakah keuntungan yang diperoleh pedagang tersebut?

2. Ayah membeli satu kaleng cat seberat $x \mathrm{~kg}$. Ketika tiga per lima bagian isinya telah digunakan, berat yang tersisa adalah $y \mathrm{~kg}$. Maka berat kosong kaleng cat tersebut adalah .... $\mathrm{kg}$.

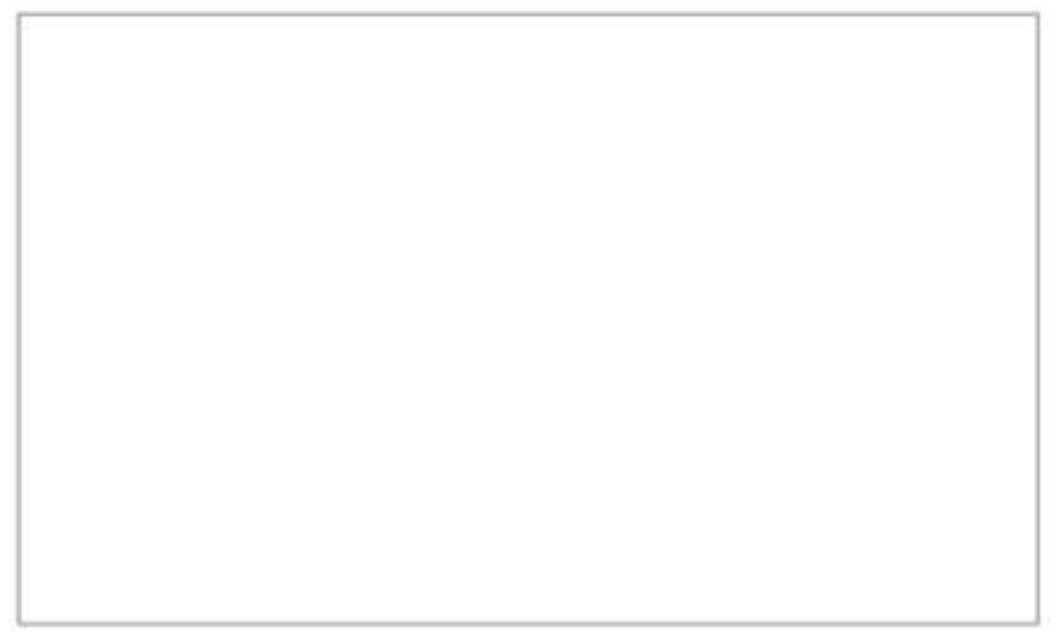

Gambar 1. Lembar Soal Post-Test

Prismatika: Jurnal Pendidikan dan Riset Matematika Vol. 3 No. 2 (2021) p-ISSN: 2654-6140, e-ISSN: 2656-4181

http://ejurnal.budiutomomalang.ac.id/index.php/prismatika 
Kegiatan bimbingan teknis writing mathematics yang dilaksanakan pada tanggal 19 November 2019 didapatkan 15 sampel baik dikarenakan ada beberapa peserta yang mengerjakan soal pre test namun tidak mengumpulkan kembali hasil pengerjaan soal post test. Berikut adalah abel yang menjelaskan perbedaan secara kualitatif hasil bimbingan teknis tersebut.

Tabel 4. Analisis Kualitatif terhadap Hasil Pre Test dan Post Test

\begin{tabular}{|c|c|c|c|c|}
\hline No. & $\begin{array}{c}\text { Nama } \\
\text { Peserta }\end{array}$ & $\begin{array}{c}\text { Analisis Hasil Pre } \\
\text { Test }\end{array}$ & $\begin{array}{c}\text { Analisis Hasil Post } \\
\text { Test }\end{array}$ & Kesimpulan \\
\hline 1. & Subjek 1 & 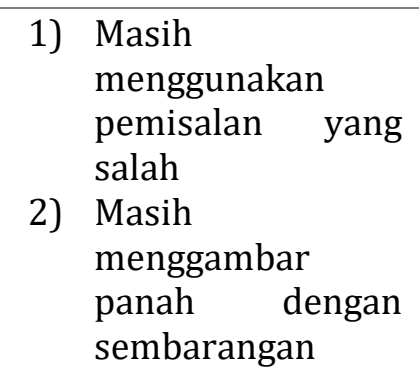 & $\begin{array}{l}\text { 1) Masih } \\
\text { menggunakan } \\
\text { pemisalan yang } \\
\text { salah } \\
\text { 2) Alur sudah mulai } \\
\text { runtut, lebih bisa } \\
\text { bercerita }\end{array}$ & $\begin{array}{l}\text { Terdapat sedikit } \\
\text { peningkatan } \\
\text { dalam } \\
\text { penguraian alur } \\
\text { cerita yang baik. }\end{array}$ \\
\hline 2. & Subjek 2 & \begin{tabular}{ll} 
1) & \multicolumn{2}{l}{ Penggunaan } \\
simbol masih \\
kurang tepat \\
2) & Masih \\
& menggambar garis \\
yang tidak & diperlukan
\end{tabular} & $\begin{array}{l}\text { 1) Masih dengan } \\
\text { penggunaan } \\
\text { simbol yang } \\
\text { kurang tepat } \\
\text { 2) Sudah tidak lagi } \\
\text { menggambar } \\
\text { garis dengan } \\
\text { sembarangan }\end{array}$ & $\begin{array}{l}\text { Pengerjaan lebih } \\
\text { rapi meskipun } \\
\text { masih terdapat } \\
\text { pemakaian } \\
\text { simbol yang } \\
\text { kurang tepat }\end{array}$ \\
\hline 3. & Subjek 3 & \begin{tabular}{ll} 
1) & \multicolumn{2}{l}{ Alur penyelesaian } \\
sudah cukup baik \\
2) & Masih ada aris \\
& beberapa baris \\
& penyelesaian yang \\
& tidak bermakna
\end{tabular} & $\begin{array}{l}\text { Beberapa baris } \\
\text { penyelesaian yang } \\
\text { tidak bermakna } \\
\text { mulai diminimalisir }\end{array}$ & $\begin{array}{l}\text { Pengetahuan } \\
\text { mengenai proses } \\
\text { yang bermakna } \\
\text { mulai diterapkan }\end{array}$ \\
\hline 4. & Subjek 4 & $\begin{array}{ll}\text { Ada beberapa } & \text { baris } \\
\text { penyelesaian } & \text { yang } \\
\text { tidak bermakna } & \end{array}$ & $\begin{array}{l}\text { Alur penyelesaian } \\
\text { mulai terlihat cukup } \\
\text { runtut }\end{array}$ & $\begin{array}{l}\text { Pemahaman } \\
\text { mengenai alur } \\
\text { penyelesaian } \\
\text { yang baik mulai } \\
\text { diterapkan }\end{array}$ \\
\hline 5. & Subjek 5 & $\begin{array}{lr}\text { Masih } & \text { terdapat } \\
\text { pemisalan } & \text { yang } \\
\text { kurang tepat } & \end{array}$ & $\begin{array}{l}\text { Alur cerita mulai } \\
\text { diperbaiki meskipun } \\
\text { belum menuju ke } \\
\text { jawaban yang benar }\end{array}$ & $\begin{array}{l}\text { Pemahaman alur } \\
\text { cerita mulai } \\
\text { meningkat }\end{array}$ \\
\hline 6. & Subjek 6 & \begin{tabular}{lr} 
Masih menggunakan & \multicolumn{2}{r}{ melum } \\
simbol yang & belum \\
dikenalkan & kepada \\
pembaca & terlebih \\
dahulu & \\
\end{tabular} & $\begin{array}{l}\text { Mulai mengenalkan } \\
\text { simbol yang akan } \\
\text { dipakai }\end{array}$ & $\begin{array}{l}\text { Pengetahuan } \\
\text { mengenai } \\
\text { penggunaan } \\
\text { simbol mulai } \\
\text { diterapkan }\end{array}$ \\
\hline 7. & Subjek 7 & $\begin{array}{lr}\text { Masih menggunakan } \\
\text { simbol yang belum } \\
\text { dikenalkan } & \text { kepada }\end{array}$ & $\begin{array}{l}\text { 1) Mulai } \\
\text { mengenalkan } \\
\text { simbol yang akan }\end{array}$ & $\begin{array}{l}\text { Pengetahuan } \\
\text { mengenai } \\
\text { penggunaan }\end{array}$ \\
\hline
\end{tabular}




\begin{tabular}{|c|c|c|c|c|}
\hline & & $\begin{array}{l}\text { pembaca } \\
\text { dahulu }\end{array}$ & $\begin{array}{l}\text { dipakai } \\
\text { 2) Alur cerita cukup } \\
\text { baik seperti pada } \\
\text { bagian pre test }\end{array}$ & $\begin{array}{l}\text { simbol mulai } \\
\text { diterapkan }\end{array}$ \\
\hline 8. & Subjek 8 & $\begin{array}{ll}\text { Ada beberapa } & \text { baris } \\
\text { penyelesaian } & \text { yang } \\
\text { tidak bermakna } & \end{array}$ & \begin{tabular}{lr}
\multicolumn{2}{l}{ Mulai meminimalisir } \\
beberapa & baris \\
penyelesaian & yang \\
tidak bermakna &
\end{tabular} & $\begin{array}{l}\text { Pemahaman } \\
\text { mengenai } \\
\text { kalimat yang } \\
\text { bermakna mulai } \\
\text { diterapkan }\end{array}$ \\
\hline 9. & Subjek 9 & $\begin{array}{l}\text { Alur cerita sudah } \\
\text { cukup baik }\end{array}$ & $\begin{array}{l}\text { Alur cerita masih } \\
\text { dipertahankan } \\
\text { dengan baik }\end{array}$ & $\begin{array}{l}\text { Pemahaman } \\
\text { mengenai } \\
\text { kronologis cerita } \\
\text { penyelesaian } \\
\text { bisa } \\
\text { dipertahankan }\end{array}$ \\
\hline 10. & Subjek 10 & $\begin{array}{l}\text { Masih menggunakan } \\
\text { pemisalan yang } \\
\text { kurang tepat }\end{array}$ & $\begin{array}{l}\text { Mulai menggunakan } \\
\text { pemisalan simbol } \\
\text { dengan cukup baik }\end{array}$ & $\begin{array}{l}\text { Pengetahuan } \\
\text { mengenai arti } \\
\text { simbol mulai } \\
\text { diterapkan }\end{array}$ \\
\hline 11. & Subjek 11 & $\begin{array}{l}\text { Alur cerita sudah } \\
\text { cukup baik }\end{array}$ & $\begin{array}{l}\text { Alur cerita masih } \\
\text { dipertahankan } \\
\text { dengan baik }\end{array}$ & $\begin{array}{l}\text { Pemahaman } \\
\text { mengenai } \\
\text { kronologis cerita } \\
\text { penyelesaian } \\
\text { bisa } \\
\text { dipertahankan }\end{array}$ \\
\hline 12. & Subjek 12 & $\begin{array}{l}\text { Alur cerita sudah } \\
\text { cukup baik }\end{array}$ & $\begin{array}{lr}\text { Penggunaan } & \text { simbol } \\
\text { biimplikasi } & \text { yang } \\
\text { kurang tepat } & \end{array}$ & $\begin{array}{l}\text { Mahasiswa } \\
\text { mencoba } \\
\text { menggunakan } \\
\text { simbol } \\
\text { ekivalensi } \\
\text { namun masih } \\
\text { salah tempat }\end{array}$ \\
\hline 13. & Subjek 13 & $\begin{array}{l}\text { Alur cerita sudah } \\
\text { cukup baik meskipun } \\
\text { soal belum dijawab } \\
\text { sampai akhir }\end{array}$ & $\begin{array}{l}\text { Penggunaan tanda } \\
\text { panah yang tidak } \\
\text { semestinya }\end{array}$ & $\begin{array}{l}\text { Mahasiswa } \\
\text { mencoba } \\
\text { menggunakan } \\
\text { simbol implikasi } \\
\text { namun masih } \\
\text { salah tempat }\end{array}$ \\
\hline 14. & Subjek 14 & $\begin{array}{l}\text { Penggunaan simbol } \\
\text { implikasi yang kurang } \\
\text { tepat }\end{array}$ & $\begin{array}{l}\text { Sudah mulai } \\
\text { menghilangkan } \\
\text { simbol implikasi } \\
\text { yang tidak pada } \\
\text { tempatnya }\end{array}$ & $\begin{array}{l}\text { Peserta mulai } \\
\text { memahami } \\
\text { penggunaan } \\
\text { simbol }\end{array}$ \\
\hline 15. & Subjek 15 & $\begin{array}{l}\text { Alur cerita } \\
\text { cukup baik }\end{array}$ & $\begin{array}{l}\text { Alur cerita masih } \\
\text { dipertahankan } \\
\text { dengan baik }\end{array}$ & $\begin{array}{l}\text { Pemahaman } \\
\text { mengenai } \\
\text { kronologis cerita } \\
\text { penyelesaian } \\
\text { bisa } \\
\text { dipertahankan }\end{array}$ \\
\hline
\end{tabular}

Prismatika: Jurnal Pendidikan dan Riset Matematika Vol. 3 No. 2 (2021) 
Berdasarkan Tabel 4 terdapat tiga hal yang cenderung dilakukan oleh mahasiswa, yaitu membuat pemisalan yang kurang tepat, penggunaan simbol yang kurang tepat, serta masih digunakannya kalimat atau pernyataan yang tidak bermakna. Namun setelah dilakukan satu kali bimbingan teknis, terlihat adanya perubahan dalam hal kualitas meskipun tidak terlalu signifikan. Hal ini dikarenakan diperlukan adanya suatu pembiasaan sehingga mahasiswa semakin terlatih dalam menuliskan/mengkomunikasikan suatu teks matematika dengan baik dan benar.

Kualitas writing skill mahasiswa tidak terlepas dari pemahaman logika dan penalaran mereka. Yang perlu diperhatikan adalah bahwa logika adalah bagian dari matematika, tetapi pada saat yang sama juga merupakan bahasa matematika. Ketika belajar suatu bahasa, khususnya menyusun suatu kalimat atau pernyataan, kita tentunya perlu memahami unsur suatu kalimat dan strukturnya, baik itu mengenai subjek, predikat, dan objek/keterangan. Intinya, logika mempelajari cara penalaran manusia, sedangkan penalaran seseorang diungkapkan dalam bahasa berupa kalimat-kalimat (Insani, 2013).

Kesulitan yang dihadapi mahasiswa perlu dihadapi dengan menyadari bahwa:

“... suatu studi yang tepat tentang logika tidak hanya memungkinkan seseorang memperoleh pengetahuan mengenai metode-metode dan prinsip-prinsip berpikir tepat, melainkan juga membuat orang yang bersangkutan mampu berpikir sendiri secara tepat dan kemudian mampu membedakan penalaran yang tepat dari penalaran yang tidak tepat. Ini semua menunjukkan bahwa logika tidak hanya merupakan suatu ilmu (science), tetapi juga suatu seni (art). Dengan kata lain, logika tidak hanya menyangkut soal pengetahuan, melainkan juga soal kemampuan atau ketrampilan". (Hidayat, 2018)

\section{KESIMPULAN DAN SARAN}

Berdasarkan hasil analisis dan evaluasi, dapat disimpulkan bahwa pemahaman writing mathematics mahasiswa berpengaruh dalam mengkomunikasikan suatu bukti pernyataan dalam matematika. Pengaruh yang dimaksud adalah pengaruh dalam hal kualitas dan perubahan skill mahasiswa yang dapat dilihat pada Tabel 4. Perubahan yang terjadi adalah perubahan ke arah yang lebih baik meskipun tidak terlalu signifikan.

Hasil analisis dan evaluasi tersebut untuk selanjutnya barangkali dapat digunakan oleh para pendidik atau pecinta Matematika dalam menyusun referensi yang berkaitan dengan writing mathematics skill. Dalam penyusunan referensi dengan topik writing mathematics skill ada baiknya memperhatikan dan mempertimbangkan "suara hati" para pembaca sehingga harapan yang ingin dicapai dalam penyusunan referensi tersebut dapat 
terwujud. Contohnya dengan melakukan survei terlebih dahulu atau mengambil data melalui kuesioner.

\section{UCAPAN TERIMA KASIH}

Ucapan terima kasih penulis sampaikan kepada seluruh responden dalam penelitian ini. Semoga kelak tulisan ini dapat memberikan manfaat yang nyata khususnya bagi mahasiswa Matematika atau Pendidikan Matematika dimana pun berada.

\section{DAFTAR PUSTAKA}

Dalen, V.D. (2013). Logic and Structure. Springer-Verlag London.

Gilbert, L. and Gilbert, J. (2009). Elements of Modern Algebra Seventh Edition. Brooks/Cole USA.

Hammack, R. (2013). Book of Proof. Virginia: Richard Hammack.

Hidayat, A. R. (2018). Filsafat Berpikir : Teknik-Teknik Berpikir Logis Kontra Kesesatan Berpikir. Pamekasan : Duta Media Publishing.

Houston, K. (2009). How to Think Like A Mathematician. New York: Cambridge University Press.

Insani, N. (2013). Logika Matematika (Catatan Kuliah). Yogyakarta : UNY.

Leary, C.C. dan Kristiansen, L. (2015). A Friendly Introduction to Mathematical Logic, Second Edition. Milne Library, New York.

Mesnil, Z. A Reference for Studying The Teaching of Logic. (2017). CERME, Dublin, Ireland.

Musthofa, I. (2016). Jendela Logika dalam Berfikir : Deduksi dan Induksi sebagai Dasar Penalaran Ilmiah. Surabaya.

Sobur, H. A. K. (2015). Logika dan Penalaran dalam Perspektif Ilmu Pengetahuan. Jambi.

Subhan, M. (2018). Pengantar Dasar Matematika. Padang : Universitas Negeri Padang.

Sudrajat, A. (2017). Bahan Kuliah : Logika. Yogyakarta : UNY.

Susilo, F. (2012). Landasan Matematika. Yogyakarta : Graha Ilmu.

Tirta, I.M. (2011). Pengantar Dasar Matematika: Pengantar Logika Matematika, Catatan Kuliah (Online). Universitas Jember.

Weruin, U. U. (2017). Logika, Penalaran, dan Argumentasi Hukum. Jakarta. 